報 文

[Nippon Nögeikagaku Kaishi Vol.61, No.6, pp. 677 681, 1987]

\title{
膜のファウリングの原因と洗浄による
}

\section{透過流束の回復性 ${ }^{\dagger}$}

\author{
神武正信, 内田幸生, 佐藤孝義*, 下田幸三* \\ 渡辺敦夫**, 中尾真一*** \\ （雪印乳業技術研究所，*雪印乳業分析センター, \\ **豊林水産省食品総合研究所, ***察京大学生産技術研究所) \\ 昭和 61 年 10 月 14 日受理
}

\author{
Filtration Membrane Fouling in Ultrafiltration of Skim Milk : \\ I. Causes and Cleaning \\ Masanobu KOUTAKE, Yukio UCHIDA, Takayoshi SATO*, Kousou SHIMODA*, \\ Atsuo WATANABE** and Shin-ichi NAKAO*** \\ Technical Research Institute and *Central Analysis Institute, \\ Snow Brand Milk Products Co., Kawagoe, Saitama 350 \\ **National Research Institute, Ministry of Agriculture, Forestry \\ and Fisheries, Yatabe, Ibaraki 305 \\ *** Institute of Industrial Science, University of Tokyo, 7-22-1, \\ Roppongi, Minato-ku, Tokyo 106
}

Skim milk was ultrafiltrated to concentration factor (CF) 6 at $50^{\circ} \mathrm{C}, 3.0 \mathrm{~kg} / \mathrm{cm}^{2}$, and $2.4 \mathrm{~m} / \mathrm{sec}$. Module UFP 10 (Rhone-Poulenc $\mathrm{Co}_{0}$ ) equipped with a polyacrylnitrile (PAN) membrane or a polysulfone (PS) membrane was used.

Visible gels were observed on both membranes after ultrafiltration (UF) of reconstituted skim milk but not after UF concentration of fresh skim milk. Fluxes of both membranes were almost the same and were about $10 \mathrm{l} / \mathrm{m}^{2} \cdot \mathrm{hr}$ at $\mathrm{CF} 6$.

The fouled membranes were cleaned successively in three steps : (1) water cleaning, (2) hand cleaning with a soft sponge to remove deposits on the membrane surface and ( 3 ) alkali detergent cleaning. Fluxes were not restored by steps (1) and (2), but step ( 3 ) restored the membrane. The protein contents of the alkali-cleaning solution increased with cleaning time. These results suggested that membrane fouling here is probably due to the milk proteins in the membrane pores.

(Received October 14, 1986)

\section{緒言}

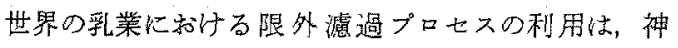
武(1)が述べているよらに, 1970 年代初頭にホエーからの 蛋白質回収に実用化されて以来，着夷に伸びてきてい， る. 牛た，牛乳のUF 処理液がらの製品化もなされてき ている。しかし，透過流束の低下をもたらすフォウリン 名（膜面污れ）は，限外濾過に拈ける大きな問題であ

†脱脂乳の限外䲣過爸理に叔けるファウリソグの研究 (第 1 報)
ク，乳業での利用に括いても例外ではない。

このフォウリングについては，一般に，ゲル分㥛もデ 几(2)で説明されているが，木村と中尾 ${ }^{(3)}$ はこれを溶質の 膜面付着による膜性能の出化であると定義し，ゲル層， スケール層虬よび目詰りなど，そのファウリング状態は 処理液によりさまさまであることを述べている。

この処理液特有のファウリング現象を理解すること

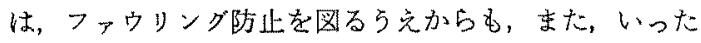
儿低下した膜性能を回復させる洗浄に和いても重要であ る、しかしながら，乳業での限外滤過の利用において， 
ファウリングと洗浄性について総合的に検討した報文は ほとんどない，とくに脱脂乳についてはフファウリング は蛋白質の膜面への付着またばダル層の形成であるとす る Gernedel と Kessler ${ }^{(4)}$ ，山村と加藤涪，就よび Patel

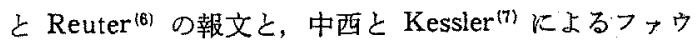
リング膜の水洗浄実験の報文などがあるのみである.

本研究では，脱脂乳の限外濾過濃縮において生ずるフ アウリング現象を，透過流束と膜の水洗，手洗和上び薬 剤洗浄々の関保に抋いて検討し，さらに，薬剤洗浄にお ける洗浄液中の活れ成分の経時変化をむ併せて検討し た.

\section{実 験 方 法}

1、装置および膜 実験に用いた限外濾過装置のフ ローダイヤグラムを Fig. 1 に示す，限外腹過モシュー ルは平膜式の UFP 10 (ローヌプーラン社製：流路, 高 さ $1.5 \mathrm{~mm} \times$ 幅 $150 \mathrm{~mm}$ ) を用いた．有效膜面積は 0.88 $\mathrm{m}^{2}\left(16\right.$ 枚 $\times 0.055 \mathrm{~m}^{2} /$ 枚) である. 使用した膜は同しく ローヌプーラン社製の IRIS 3038 膜 (ポリアクリロニト リ儿膜：PAN) おょび三井石油化学工業社製の MPS 3400 膜（ポリスルフォン膜：PS）である。これらの膜 仕様を Table I $I^{(8,9)}$ に示す.

2. 原料乳之その調製法還元脱脂乳と生脱脂乳の 2 種類を用いた。、いずれる牛乳用濾紙（ミルパップ）で 前濾過した後，限外滤過装置に供給した。

還元脱脂乳は，雪印乳業社製の脱脂粉乳を目標固形分 $8.5 \%$ Kなるよう温水 $\left(50^{\circ} \mathrm{C}\right)$ にて溶解し， 1 時間保持 後，実験温度に調温して実験に供した。

生脱脂乳は全酪連新束京工場より入手し，殺菌 $\left(65^{\circ} \mathrm{C}\right.$, 30 分）後，実験温度に冷却して用いた。

3. 瀑縮実験亡漂縮倍率 脱脂乳の限外濾過処理 は，回分淟縮方式で行い，透過液の瞬間量（透過流束） と積算量を測定した，濃縮倍率 (concentration factor : CF) は仕込量を濃縮液量（二仕达液量一積算透過液量） で除して求めた。

実験条件は，初期脱脂乳量 $130 \mathrm{~kg}$ ，運転温度 $50^{\circ} \mathrm{C}$, 平均運転圧: (大口 $3.5 \mathrm{~kg} / \mathrm{cm}^{2}+$ 出口 $2.5 \mathrm{~kg} / \mathrm{cm}^{2}$ ) $/ 2=3$ $\mathrm{kg} / \mathrm{cm}^{2}$, 膜面流速 $2.4 \mathrm{~m} / \mathrm{sec}$ である. 限外濾過処理は, 透過流束が急激に低下した後安定する時点すなかち， 澧縮倍率6にて終了した，その後，装置内の濃縮乳を回 収し，水で白濁がなくなるまでゆっくりゆすぎ，この限 外滤過膜をファウリンダ膜とした。

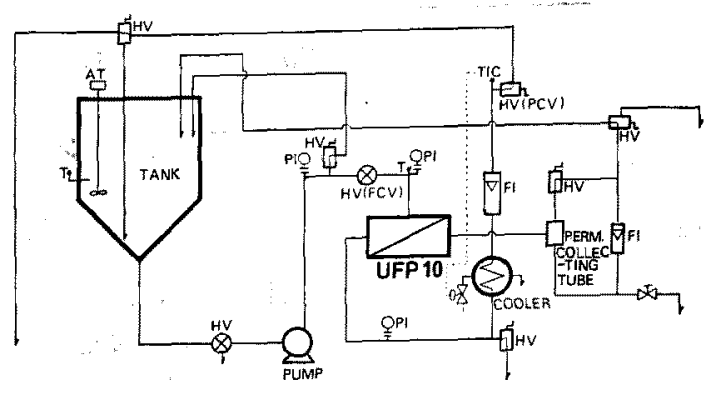

Fig. 1. Flow Diagram of UF Pilot Plant. T, temperature indicator; AT, agitator ; $\mathrm{HV}$, hand valve; $P I$, pressure indicator; FCV, flow control valve; $F I$, flow indicator; PCV, pressure control valve ; TIC, temperature indicator and controller.

4. ファウリンク膜面のゲル確認 モジュールを分 解して, ファウリンダ膜面の目視之触感にてゲル層の有 無の確認老行った。

5. 膜洗浄テスト 生脱脂乳でファウリングが生じ た限外澛過膜の洗浄性テストを Fig. 4 に示した手順で 行い，各洗浄ごとに透過流束の回復性を測定した，洗剤 洗浄においては，へンケル白水社製の Ultrasil-25（塩素 化フルカリ洗剈) $1 \%$ 溶液 $30 \mathrm{~kg}$ を用いて循環洗淨法を 実施し，経時的に洗浄液のサンブリングを行った。

これらの洗浄テストに用いた水はすべて $0.8 \mu \mathrm{m}$ 精密 滤過膜にて濾過した水道水を用いた。

6. 分析方法 原料乳拉よび濃縮乳性試料そのま ま，洗浄液試料各 $1 l$ は温浴上で濃縮後，分析に供した。

一般成分は食品分析法 ${ }^{(10)}$ 火従い，全固形分は常压加熱 法により, 蛋白質はケールダール法 (係数 : 6.38), 脂肪 はレーゼゴットリーブ法, 乳糖はレインエイノン法, 灰 分性乾式灰化法にて分析した。

また，洗浄液の無機成分分析は，試料を淔硫酸と過酸 化水素を用いて湿式分解後，原子吸光法にて，原子吸光

Table I. Specification of Membranes

\begin{tabular}{|c|c|c|}
\hline Membrane & IRIS 3038 & MPS 3400 \\
\hline Maker & Rhone-Poulenc & $\begin{array}{l}\text { Mitsui } \\
\text { Petro-chemical } \\
\text { Industries }\end{array}$ \\
\hline Material & $\begin{array}{l}\text { Poly- } \\
\text { acrylnitrile (PAN) }\end{array}$ & fone (PS) \\
\hline $\begin{array}{l}\text { Cut off value } \\
\text { (MW) }\end{array}$ & $15,000 \sim 20,000$ & $30,000 \sim 40,000$ \\
\hline $\mathrm{pH}$ allowance & $1 \sim 10$ & $1 \sim 13$ \\
\hline Max temp. $\left({ }^{\circ} \mathrm{C}\right.$ & C) 60 & 90 \\
\hline
\end{tabular}


Table II. Composition of Skim Milk and Retentate of Ultrafiltration at Different Concentration Factors

\begin{tabular}{lrrrcc}
\hline & $\begin{array}{c}\text { Total } \\
\text { solid }\end{array}$ & Protein & Fat & Lactose & Ash \\
\hline Skim milk & 8.74 & 3.08 & 0.19 & 4.52 & 0.76 \\
Retentate & & & & & \\
CF 2 & 11.83 & 5.89 & 0.37 & 4.49 & 1.00 \\
CF 3.5 & 17.33 & 10.18 & 0.65 & 4.50 & 1.43 \\
CF 6 & 26.50 & 18.16 & 1.15 & 4.22 & 2.07 \\
\hline
\end{tabular}

光度計 HITACHI 180-80 型を用いて行い, $\mathrm{Na}, \mathrm{K}$, Ca を測定した. P は灰化後, アレン法(11)で測定した.

\section{結果と考察}

\section{1. ゲル観察テスト}

生脱脂乳および還元脱脂乳を6 倍まで限外濾過濃縮し たときの透過流束 (Flux) の变化を Fig. 2 亿示す. 透過

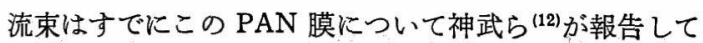
いるとおう，高い值を示した６倍までの所要時間は透 過流束の高いほうから，それぞれ 127 分，132 分，142 分であった，濃縮乳の一般組成においては，すでに神武 ら ${ }^{(21)} か^{\prime}$ 報告しているよらに, 生脱脂乳と還元脱脂乳との 違いは注とんどなく，また，膜による違いも認められな かった．原料乳から 6 倍濃縮までの成分変化の 1 例を Table II と示す.

、透過流束は濃縮が進むにつれ減少し，生脱脂乳と還元 脱脂乳とではその低下率は多少異なるが, いずれの場合 も $3 \sim 4$ 倍のところで急激な透過流束の低下が起きてい る.この低下は, 膜面にゲル層が発生したことによるる のと推定した. そこで, 透過流束が注ほ平衡に達した 6 倍濃縮時で限外濾過濃縮を終了乙，水ゆすぎ後，膜面観 察を行った. 還元脱脂乳では, Fig. 3 に示すようにゲル の存在が確認されたが, 生脱脂乳では認められなかっ た.この違いは, 還元脱脂乳の場合, 蛋白質が一度脱水 されているため，還元しても溶質として不安定で，濃度 分極により膜面上の濃度が上昇しゲル化したものと判 断した。このゲルは，還元脱脂乳の場合，いずれの膜で も観察された. しかし, このゲルの存在にもかかわら ず，還元脱脂乳の透過流束は，濃縮倍率 6 の時点で，生 脱脂乳のそれとほぼ等しい值となっている。このこと は, ケ゚ルが透過流束にほとんど影響を及ぼしていないこ とを示唆している，また，生脱脂乳の場合，たとえ目視 や触感で感知できるゲルが存在したとしても, 透過流束

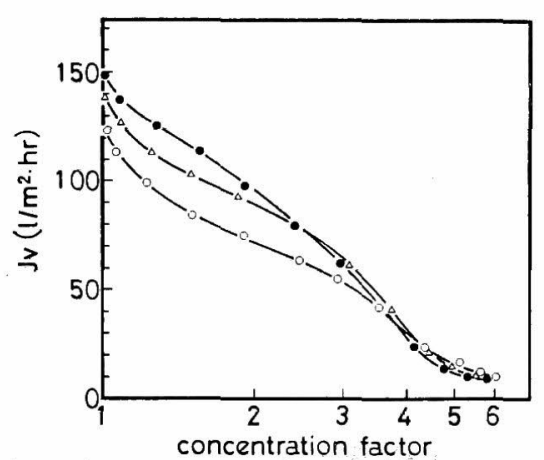

Fig. 2. Flux Changes in UF of Skim Milk at $50^{\circ} \mathrm{C}, 3.0 \mathrm{~kg} / \mathrm{cm}^{2}$ and $2.4 \mathrm{~m} / \mathrm{sec}$. $O$, PS membrane, fresh skim milk; $\bullet$, PS membrane, reconstituted skim milk; $\triangle$, PAN membrane, fresh skim milk.

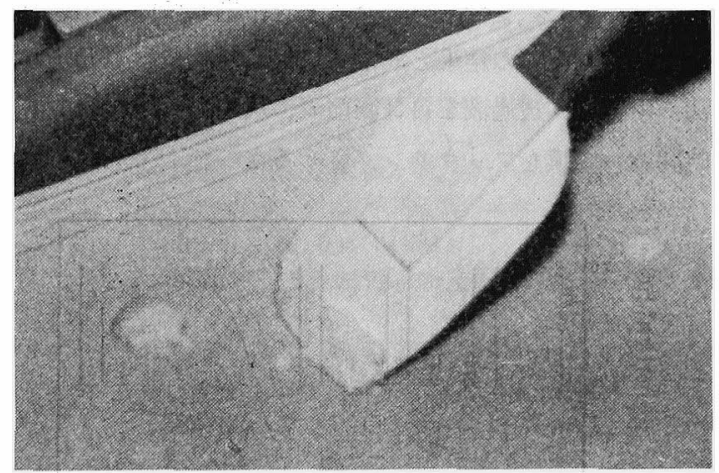

Fig. 3. Gel Formed on the Membrane in UF Concentration of Reconstituted Skim Milk up to $\mathrm{CF} 6$.

には影響を及洼さないものと推測される。この点は，後 述するように, 膜面の手洗い前後の水透過流束が注上ん と゚変化しないことからも確認された。

膜種による透過流束の違いは, 生脱脂乳に拈いて, 濃 縮倍率 4 以下では PAN 膜のほらか゚PS 膜より高い透過 流束を示したが，濃縮がさらに進むにつれ，透過流束は いずれの膜でも低下していき，その傾向は同じであっ た．高濃度になるほど，膜種による影響よりも濃縮分極 およびファウリングによる透過流束低下のほうが優位と なることを示している。

\section{2. 洗浄テスト}

（1）水洗浄と手洗 洗浄による透過流束の回復性 を Fig. 4 亿示す. 水洗浄 1 飞打いては透過流束の回復 はわずかに PS 膜にみられるが， ほとんど水洗浄の効果 はなかった．また，手洗 2 前後でみられる PS 膜の透過 
流束の回復性も微々たるもので, 手洗の效果はないとい 觉る。手洗によって膜面の付着物（目視，触感では観察 されなかったが）は除去されて抢り，それです，手洗の 効果がなかったことは、(1)フォウリングが生じた膜の水 の透過流束の低下は付着層，ゲル層によるものではな く，目詰りによること，扎ざ(このファウリンダによ る透過流束の低下は，水洗浄や，手洗では回復しないこ とを示している。なお，PS 䠑が，水洗浄時，PAN 膜よ りもやや高い透過流束を示しているが、これは神武らが 報告しているPAN 膜との孔径の違い(13iや，目詰り物質 のおのおのの膜との親和性が異なるため，目詰り状態が 㱖っていることによるものであるう。

中西と Kessler (7) は脱脂乳のU UF 処理でフォウリン グが生じた膜の水洗浄テストに扰いて，30 分間で水の 透過率の 70\% まで回復したことを報告している。この 結果は, 本実験の結果と異なっているが, 彼らの実験方 法の場合は，透過液を再び濃縮液に戻す全䛻環運転を1 時間行って膜をファウリングさせるもので, ファウリン

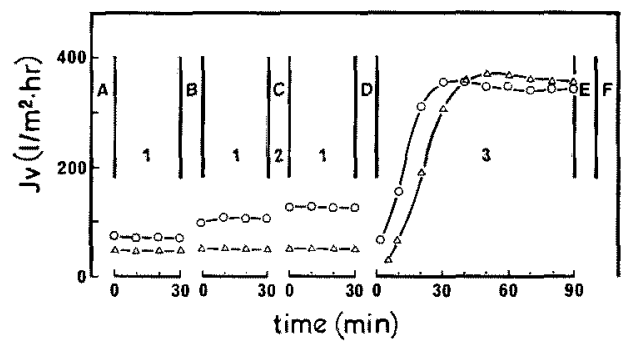

Fig. 4. Changes of Flux (Jv) of Fouled Membranes (-O-PS Membrane and- $\triangle$-PAN Membrane) with Time during Cleaning with (1) Water, (2) by Hand with Soft Sponge, and (3) with Detergent, $1 \%$ Ultrasil-25 at $45^{\circ} \mathrm{C}$, $1 \mathrm{~kg} / \mathrm{cm}^{2}$ and $2.8 \mathrm{~m} / \mathrm{sec}$ :

\begin{tabular}{|c|c|c|}
\hline & $\begin{array}{c}\text { Membrane cleaning } \\
\text { steps }\end{array}$ & Other steps \\
\hline 1 & Water cleaning & $\begin{array}{l}\text { A Removing retentate } \\
\text { and rinsing } \\
\text { B 1st CIP of UF plant } \\
\text { by-passed UF module }\end{array}$ \\
\hline 2 & $\begin{array}{l}\text { Hand cleaning of UF } \\
\text { membrane with soft } \\
\text { sponge to remove } \\
\text { gels or deposits on } \\
\text { membrane }\end{array}$ & $\begin{array}{l}\text { C during 2nd CIP of } \\
\text { UF plant } \\
\text { D Rinsing }\end{array}$ \\
\hline 3 & $\begin{array}{l}\text { Alkali-cleaning, } \quad 1 \% \\
\text { Ultrasil-25 }\end{array}$ & $\begin{array}{ll}\text { E Rinsing } \\
\text { F Pure water flux } \\
\\
\text { measurement }\end{array}$ \\
\hline
\end{tabular}

グの程度は低いと推定され；また使用膜は酿酸せルロー ス膜で本実験の使用膜と材質が翼なって和りこれらの要 因が水洗浄効果を大きくしたものであるら。

（2）アルカリ洗浄 上記の水洗浄と手洗後に実施 したアルカリ洗浄で，透過流束は争速に回復し，PS 膜 で 30 分, PAN 膜では 40 分で定常に達した.

洗浄液中心無機質の経時变化を. Table III に示す. 無 穖質は経時的にほとんど变化なく、これらがファウリン グ物質になっているとはい点ない，洗浄液の成分中，経 時的に最も変化したものは蛋白質で，その様子を Fig. 5 に示す。この結果から蛋白質がファウリング物質である と結論した。

PAN 膜は，透過流束の回復曲線とほぼ亚行して，蛋 白質が増加しているが，長時間洗浄（90分）では再び減 少しており，雷白質の膜への再付着が示惨される. しか しながら，Fig.4 に示すよらに透過流束の低下には大き

Table III. Change of Mineral Concentrations of Alkali Solution, $1 \%$ Ultrasil-25, with Time.

\begin{tabular}{|c|c|c|c|c|c|c|c|c|}
\hline \multirow{3}{*}{$\begin{array}{l}\text { Sampling } \\
\text { time } \\
\text { (min) }\end{array}$} & \multicolumn{6}{|c|}{ Conc. $(\mathrm{mg} / \mathrm{l})$} & \multirow{2}{*}{\multicolumn{2}{|c|}{ abrane }} \\
\hline & \multicolumn{4}{|c|}{ PS membrane } & \multicolumn{2}{|c|}{ PAN mem } & & \\
\hline & $\mathrm{Na}$ & $\mathrm{K}$ & $\mathrm{Ca}$ & $\mathrm{P}$ & $\mathrm{Na}$ & $\mathrm{K}$ & $\mathrm{Ca}$ & $\mathrm{P}$ \\
\hline 0 & 1400 & 3.9 & 26 & 31 & 1150 & 4.5 & 34 & 29 \\
\hline 1 & 1310 & 3.9 & 26 & 31 & 1180 & 4.5 & 36 & 30 \\
\hline 15 & 1390 & 4. 0 & 28 & 30 & 1110 & 4.5 & 36 & 30 \\
\hline 30 & 1310 & 4.0 & 27 & 31 & 1110 & 4.5 & 36 & 29 \\
\hline 60 & 1320 & 4.2 & 27 & 31 & 1110 & 4.5 & 35 & 28 \\
\hline 90 & 1310 & 4. 2 & 27 & 29 & 1150 & 4. 5 & 35 & 29 \\
\hline
\end{tabular}

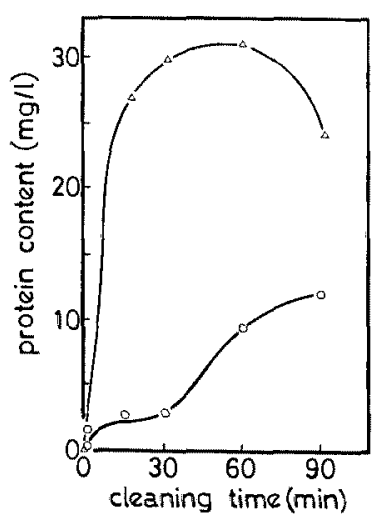

Fig. 5. Change of Protein Content in the Detergent Solution, 1\% Ultrasil-25, Used for PAN $\left(-\Delta^{-}\right)$and PS (-O-) Membranes with Time. 
く現れていない、これは洗剂により蛋白質が変質してい ることにより，再付着しても目詰り效果が減少している ためであらら。

他方，PS 膜に执いては，透過流束の回復とは並行子 ボに，洋れて洗浄液中の蛋白質が增加している、これは PS 膜の孔径がふでるい(12)であるため，径の大きな孔が 早く洗浄され，この部分に占める透過流束の割合が大き く，早い透過流束の回復になったものと推察される.

PAN 膜と PS 膜それぞれの洗浄液中の蛋白質量の 違いは，膜に目詰りした蛋白質量の違いによるものであ 万5. PAN 膜, PS 膜八の蛋白質のファウリング推定量 はそれでれ $0.11 \mathrm{mg} / \mathrm{cm}^{2} ， 0.04 \mathrm{mg} / \mathrm{cm}^{2}$ であった。

アルカリ洗浄後の純水透過流束は, 使用前のそれと比 較して, PAN 膜で 100\%, PS 膜で $75 \%$ の回復率であ り,このアルカリ洗浄の有効性が確認された。

以上の結果は，透過流束の低下をもたらすファウリン グは，蛋白質の膜面付によるものとする Gernede と Kessler ${ }^{(4)}$ ，山柇と加藤(5)，Patel とReuter ${ }^{(6)} \sigma$ 説と異な り，蛋白質の目詰りであることを示唆するものである。 このファウリング現研について，さらに第2 報で詳しく 検討する。

\section{要 約}

生脱脂乳 $\left(65^{\circ} \mathrm{C}, 30\right.$ 分殺菌）および還元脱脂乳を2 種 の膜(ポリアクリロニトリル膜: PAN 膜, ポリスルフ *ン膜: PS 膜) で, 限外濾過 $\left(50^{\circ} \mathrm{C}, 3 \mathrm{~kg} / \mathrm{cm}^{2}, 2.4\right.$ $\mathrm{m} / \mathrm{sec}$ ) し， 6 倍まで濃縮した，膜透過流束はファウリ ングにより低下したが，これらの膜表面のゲルの有無 を，目視および触感で確認したところ，還元脱脂乳の場 合のみ，膜種に関係なく，ゲルが確認された。しかし， 透過流束は，ゲルの有無に閔保なく，来た膜種にも関係 なく，6倍濃樎付近で約 $10 \mathrm{l} / \mathrm{m}^{2} \cdot \mathrm{hr}$ に収束した。 これ は，ゲルは唀過流束にあまり影響を及ほさないことを示
咬するものである。

さらに，生脱脂乳でファウリングが生じた膜の洗浄テ ストを実施した。本洗浄です，また膜面をスポンジで手 洗しても，いずれの場合も，純水透過流束は活と儿ど回 復しなかった.この後に実施したアルカリ(Uitrasil-25, $1 \%$ ) 洗浄により，純水透過流束は $75 \%$ (PS 膜) $100 \%$ (PAN 膜) 回復した.こ机らの洗浄液のファウリング物 質成分中，蛋白質含量のみが経時的に増加した。

これらの結果は，脱脂乳の限外濾過滥縮時，透過流束 の低下をもたらすファウリングは乳蛋白質の膜細孔への 目詰りであることを示晙している.

本研究は，食品産業膜利用技術研究組合 ${ }^{(14)}$ の研究の 一つとして行われたものである。

(1) 神武正信: 膜, 10，87 (1985).

(2) W. F. Blatt, A. Dravid, A. Michaels, and L. Nelson: "Membrane Science and Technology," ed. by J.E. Flinn, 1970, p. 47.

（3）木村尚史，中尾真一：「人工膜」，星狧，木 村尚史, 円沢宏共編，化学同人，1981，p.65.

(4) G. Gernedel and H. G. Kessler : Verfahrenstechnik, 15, 646 (1981).

（5）山村健治，加藤宏夫：住友重機械技報，29，86 (1981).

(6) R.S.Patel and H. Reuter:Milchwissenschaft, 40, 592 (1985).

（7）中西一弘, H. G. Kessler :「食品化学工学」, 化 学工学協会・食品化学工学研究会編, 化学工学 協会, 1983, p.37.

(8) ローヌプーラン社カタロク゚.

(9) 三井石油化学工莱(株)力夕口多。

（10）日本食品工業学会, 食品分析法編集委員会：「食 品分析法」, 光林, 1982 .

(11) R. J. L. Allen : Biochem.J., 34, 858 (1940).

（12）神武正信，内田幸生，佐藤孝義，下田幸三：雪 印乳業技街研究所報告，83号，67 (1986)。

（13）神武正㒀，内田幸生，木村利昭，相良康重，渡 辺敦夫, 中尾真一: 膜, 10,310 (1985) .

（14）雚波靖尚：食品工業，12下，28（1983）. 